\title{
THE POTENCY OF LOCAL ISOLATES FROM NORTH SUMATERA IN THE DEGRADATION OF NAPHTALENE
}

\author{
Nunuk Priyani, Erman Munir, Irmalisyah W. Panjaitan, and Kabul Warsito \\ Department of Biology, Faculty of Mathematics and Natural Sciences, \\ University of Sumatera Utara \\ Correspondent : priyanin@yahoo.com
}

ABSTRACT

The potency of biosurfactant-producing bacteria isolated from oil-contaminated coast, Belawan North Sumatera, in the degradation of hydrocarbon compound such as naphthalene has been studied. Thirteen isolates has been obtained using Bushnell Haas Agar containing $2 \%$ naphthalene as the sole carbon source. The bacterial growth was observed using Standard Plate Count method. The ability of each isolates to produce bioactive-surface compound was determined. A drop-collapsing test was performed to examine the activity of each biosurfactant. All isolates tested grew well in Bushnell Haas Broth medium. Among those, two isolates were able to remove almost all (99\%) naphthalene from the medium during 15 days. Those two isolates have also shown highest concentration of biosurfactant production which is $75.180 \mathrm{ppm}$.

Key words: local isolates, biosurfactant, naphthalene degradation.

\section{INTRODUCTION}

Indonesia, as many other countries has a serious problem regarding oil pollution on the sea. The pollution not only because of tanker accident, tanker leaking, but also drilling, oil processing and other activities including loading and unloading actitivities (Fachrudin, 2004). On the other hand, sea is good source of bioactive compounds which could be very potential (Abraham, 2004). According to Parra et. al. (1989) many biosurfactant-producing bacteria have been isolated from oil - contaminated sites. Biosurfactant production by bacteria are closely related to the ability of bacteria in consuming hydrocarbon compounds as their substrates. Microorganism with high production of biodurfactant shows high ability of hydrocarbon degradation. These kinds of bacteria have high potency to reduce oil pollution on the sea (Berthrand, 1994).

Crude oil is the main contaminat on the sea. This oil consists of $50-98 \%$ hydrocarbon compound, and the rest is non hydrocarbon compound such as sulphur, nitrogen, and some heavy metals. One component of hydrocarbon compound in crude oil is Polycyclic Aromatic Hydrocarbon (PAH) which includes naphthalene, anthracene and phenanthrene. Naphthalene is the simplest PAH with two rings structure. Naphthalene is known as mutagen, so its concentration in the environment has to be controlled.

Biosurfactant is an amphiphilic compound produced by microorganism. It has both hydrophobic and hydrophilic groups that function to reduce the surface tension of molecules or tension between each molecule surface. Therefore its potency in replacing synthetic surfactant is quite promising (Gautam, 2006). Biosurfaktan has wide applications; in oil industry, it can promote the product up to $30 \%$; in food industry, it function as food additive and emulsifier. Moreover it can be used as agent for bioremediation of oil or heavy metal contaminated sites. Many biosurfactant-producing bacteria have been patented in developed countries such America, Australia, Japan etc. In Indonesia, the study about biosurfactant-producing bacteria is still limited. 


\section{MATERIALS AND METHODS \\ Isolation of bacteria}

One $\mathrm{ml}$ of water sample from oil contaminates sea was spread on several Petri Dishes with Bushnell Haas Agar containing 2\% naphtalene as the sole carbon source. They were incubated at $30^{\circ} \mathrm{C}$ in incubator for about 2 week. The colonies that grew were the bacteria that were able to digest naphthalene. The colonies were then purified and characterized based their morphology and simple biochemical test. All isolates were refrigerated and stored in nutrient agar.

\section{Culture condition}

As many as $2 \mathrm{ml}$ of each isolate was standardized to Mac Farland solution which equal to $10^{8} \mathrm{cell} / \mathrm{ml}$ was inoculated into Bushnell Haas Broth containing $20 \mathrm{mg} \mathrm{l}^{-1}$ naphthalene. As a control, there was a Bushnell Haas Broth medium without bacterial inoculation. All culture were gromn in waterbath shaker at $125 \mathrm{rpm}$, at $30^{\circ} \mathrm{C}$ in dark condition (all cultures were covered with aluminium foil). The parameters observed were bacterial population, the biosurfactant activity, the volume of biosurfactant produced, and the ability to degrade naphthalene. the bacterial population was observed on day $0^{\text {th }}, 5^{\text {th }}, 10^{\text {th }}$, and $15^{\text {th }}$ while biosurfactant activity, the production of biodurfactan, and the residue od naphthalene were observed on day $15^{\text {th }}$.

\section{Bacterial Growth}

The bacterial population was estimated using Standard Plate Count (SPC) method. Each colony that grew was counted using colony counter.

$$
\text { The number of bacteria }=\frac{\text { The number of colony }}{\text { Dilution factor }}
$$

\section{Screening of Biosurfactant Activity}

Biosurfactant activity of each isolate was examined by Drop Collapsing Test that was modified (Jain et. al. 1991). Each culture was centrifugated at $6.000 \mathrm{rpm}$ for 10 minutes to separate supernatant from bacteria. Four $\mathrm{ml}$ of supernatant was added into the mixture of 4 $\mathrm{ml} \mathrm{N}$-heksan and $2 \mathrm{ml}$ of aquades. The mixture was vortexed for 10 second and left it undisturbed for 1 minute. Observe the stable emulsion that formed. Measure the volume.

\section{Production and quantification of biosurfactant}

The concentration of biosurfactant was analyzed by Orsinol Method that has een modified (Chandrasekaran \& BeMiller, 1980). Four $\mathrm{ml}$ of superntan was extracted with $2 \mathrm{ml}$ of diethylether for 5 minutes, the ether layer was removed. The extraction was repeated 3 times. The ether layer was dried out dissolved into $2 \mathrm{ml}$ of $0.05 \mathrm{M}$ sodium bicarbonate, the mixture was vortexed and added with 3.7 orsinol solution, heated to the boil, and left at room temperatre for 15 minutes. The concentration of biosurfactant was measured using Spectrophotometer UV-Visible Shimadzu1240 at $421 \mathrm{~nm}$ with rhamnose as the standard.

\section{Analyses of naphthalene residue}

At the end of incubation, all culture were added with $0.1 \mathrm{~N}$ of $\mathrm{NaOH}$ to adjust the $\mathrm{pH}$ into 
12. The media were filtrated using filtrate paper. Each filtrate was poured into separator funnel and was added with $10 \mathrm{ml}$ of $\mathrm{N}$-hecsan, shake well for 15 minutes and left until 2 layers formed. The lower layer, which consists of water was discharged. The extraction was repeated 3 times. As many as $1 \mu$ of eacd sample was injected into Gas Chromatography Hewlet Packard 6890 to analyze the concentration of naphthalene left.

\section{RESULTS AND DISCUSSION}

Microorganisms capable of degrading PAH exist in most environment, and it is thus not surprising that most success to date has been achieved with strategies that stimulate the biodegradative capacity of microbial communities. Microorganisms have been found to degrade PAH as carbon and energy source, as a mean of reducing PAH toxicity and as cometabolic substrates (Johnsen et. al. 2005). The result of isolation, we obtained 13 isolates from Belawan sea shore. All isolates showed different characters both morphologically and biochemically as shown by the following picture.

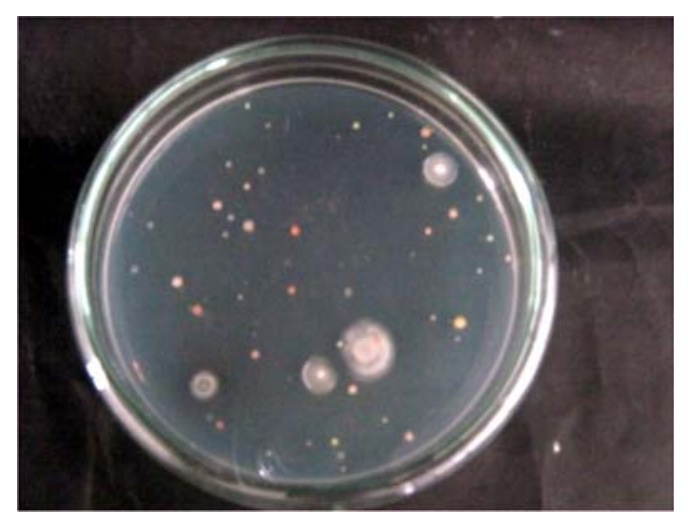

Figure1. Bacterial isolates growth on Bushnell Haas Agar containing $2 \%$ of naphthalene as the sole carbon source.

Table 1. Morphology characters of colonies anf cells of isolates.

\begin{tabular}{lllllll}
\hline Bacterial & \multicolumn{5}{c}{ Morphology of colony and cells } \\
Isolate & Colony Shape & Colony edge & Elevation & Colony color & Cell shape & Cell arrangement \\
\hline Sp. 1 & Circular & Undulate & Flat & Light yellow & Coccus & Mono/Diplo \\
Sp. 2 & Circular & Entire & Flat & Light Brown & Coccus & Mono/Diplo \\
Sp. 3 & Circular & Undulate & Convex & Beige & Coccus & Mono/Diplo \\
Sp. 4 & Irregular & Entire & Flat & Light Brown & Coccus & Mono/Diplo \\
Sp. 5 & Irregular & Entire & Flat & Beige & Coccus & Mono/Diplo \\
Sp. 6 & Circular & Entire & Flat & Beige & Coccus & Mono/Diplo \\
Sp. 7 & Circular & Entire & Flat & Bright yellow & Coccus & Mono/Diplo \\
Sp. 8 & Irregular & Entire & Flat & Light Brown & Coccus & Mono/Diplo \\
Sp. 9 & Circular & Undulate & Convex & Bright orange & Coccus & Mono/Diplo \\
Sp. 10 & Circular & Lobate & Flat & Light Brown & Coccus & Mono/Diplo \\
Sp. 11 & Circular & Entire & Umbonate & Bright orange & Coccus & Mono/Diplo \\
Sp. 12 & Circular & Entire & Flat & Orange & Coccus & Mono/Diplo \\
Sp. 13 & Circular & Entire & Flat & Beige & Coccus & Mono/Diplo \\
\hline
\end{tabular}

Only three isolates are able to utilize citrate as a carbon source (citrate positive), while most isolates are able to ferment glucose (TSIA positive), to digest gelatin (gelatin positive), to break down hydrogen peroxide into water and oxygen and are motil. 
Table 2. Simple Biochemical Test of Isolates

\begin{tabular}{|c|c|c|c|c|c|c|}
\hline \multirow{2}{*}{$\begin{array}{l}\text { Bacterial } \\
\text { Isolate }\end{array}$} & \multicolumn{5}{|c|}{ Biochemical Test } & \multirow[t]{2}{*}{ Gram Staining } \\
\hline & TSIA & Citrate & Motility & Gelatin & Catalase & \\
\hline Sp. 1 & + & + & + & + & + & - \\
\hline Sp. 2 & + & - & + & + & + & - \\
\hline Sp. 3 & + & - & + & + & + & - \\
\hline Sp. 4 & - & - & + & - & - & - \\
\hline Sp. 5 & + & - & - & - & - & + \\
\hline Sp. 6 & + & _ & + & + & + & - \\
\hline Sp. 7 & + & + & + & + & - & - \\
\hline Sp. 8 & + & - & + & + & + & + \\
\hline Sp. 9 & + & - & + & - & + & - \\
\hline Sp. 10 & + & _- & + & - & + & + \\
\hline Sp. 11 & + & - & + & + & + & - \\
\hline Sp. 12 & + & - & + & + & + & - \\
\hline Sp. 13 & - & + & + & + & + & - \\
\hline
\end{tabular}

All isolates grew well utilising naphthalene as carbon source and energy. The initial population was $4.0 \times 10^{6} \mathrm{cell} \mathrm{ml}^{-1}$. On the first day of observation, all isoltes grew slowly while on the second and last days of incubation the population of all isolates increased significantly and constantly. Among all isolate tested, isolate Sp.7 showed the fastest growth with the number of cells reached $19 \times 10^{10} \mathrm{cells} / \mathrm{ml}$. The lowest population was shown by isolate Sp. 13 with the population was $4.4 \times 10^{10} \mathrm{cells} / \mathrm{ml}$. The complete data about bacterial growth was shown in Table 3 bellow.

Table 3. Bacterial Population (cells $/ \mathrm{ml}$ ) on day 5th, 10th, and 15th. The initial population was 4.4 x $10^{6}$ cells $/ \mathrm{ml}$.

\begin{tabular}{cccc}
\hline \multirow{2}{*}{ Bacterial Isolates } & \multicolumn{3}{c}{ Number of Cells (cells/ml) } \\
\cline { 2 - 4 } Sp. 1 & $5^{\text {th }}$ day & $10^{\text {th }}$ day & $15^{\text {th }}$ day \\
\hline Sp. 2 & $2.9 \times 10^{7}$ & $3.3 \times 10^{9}$ & $4.7 \times 10^{10}$ \\
\hline Sp. 3 & $2.8 \times 10^{7}$ & $3.5 \times 10^{9}$ & $4.7 \times 10^{10}$ \\
\hline Sp. 4 & $3.2 \times 10^{7}$ & $9.3 \times 10^{9}$ & $10.0 \times 10^{10}$ \\
\hline Sp. 5 & $7.7 \times 10^{7}$ & $10.0 \times 10^{9}$ & $12.0 \times 10^{10}$ \\
\hline Sp. 6 & $5.3 \times 10^{7}$ & $6.6 \times 10^{9}$ & $7,6 \times 10^{10}$ \\
\hline Sp. 7 & $5.7 \times 10^{7}$ & $7.6 \times 10^{9}$ & $8.0 \times 10^{10}$ \\
\hline Sp. 8 & $9.4 \times 10^{7}$ & $15.0 \times 10^{9}$ & $19.0 \times 10^{10}$ \\
\hline Sp. 9 & $4.4 \times 10^{7}$ & $8.3 \times 10^{9}$ & $9.0 \times 10^{10}$ \\
\hline Sp. 10 & $2.9 \times 10^{7}$ & $4.6 \times 10^{9}$ & $5.3 \times 10^{10}$ \\
\hline Sp. 11 & $2.2 \times 10^{7}$ & $3.0 \times 10^{9}$ & $4.6 \times 10^{10}$ \\
\hline Sp. 12 & $4.2 \times 10^{7}$ & $8.2 \times 10^{9}$ & $9.1 \times 10^{10}$ \\
\hline Sp. 13 & $5.7 \times 10^{7}$ & $7.9 \times 10^{9}$ & $8.5 \times 10^{10}$ \\
\hline S & $2.8 \times 10^{7}$ & $3.2 \times 10^{9}$ & $4,4 \times 10^{10}$
\end{tabular}

Note: the initial population was $4.4 \times 10^{6}$ cells $/ \mathrm{ml}$.

Growth assays revealed that strain CJ2 is inhibited by naphthalene concentrations of 78 microM (10 p.p.m.) and higher, and the inhibition of growth is accompanied by the accumu- 
lation of orange-coloured, putative naphthalene metabolites in the culture medium. (Pumphrey, and Madsen, 2007).

Based on biosurfactant activity, the isolate that showed the highest activity was Sp. 4 with the emulsion volume was $2.89 \mathrm{ml}$, while the lowest one was Sp. 13 with total volume of emulsion was $0.43 \mathrm{ml}$. Isolat Sp. 4 and Sp. 13 produced the highest and the lowest concentration of biosurfactant upto 74.180 ppm and 14.786 ppm respectively. Isolate Sp. 4 was very promising since it showed the highest biosurfactant activity and produced the highest concentration of biosurfactant, eventhough the growth was not as high as Sp. 7. Meanwhile Sp. 13 is the isolate that shwow the lowest populationt activity, and the smalest conentration of biosurfactant.

Table 4. Biosurfactant Activity Analyzed by "Drops Collapsing method" of Isolates and the concentration of biosurfactant produced.

\begin{tabular}{ccc}
\hline Bacterial Isolates & Volume of emulsion $(\mathrm{ml})$ & Biosurfactant conc. $(\mathrm{ppm})$ \\
\hline Sp. 1 & 1.56 & 18.763 \\
\hline Sp. 2 & 0.57 & 15.806 \\
\hline Sp. 3 & 0.79 & 16.786 \\
\hline Sp. 4 & 2.89 & 75.180 \\
\hline Sp. 5 & 0.80 & 20.455 \\
\hline Sp. 6 & 2.19 & 45.531 \\
\hline Sp. 7 & 2.45 & 61.547 \\
\hline Sp. 8 & 1.99 & 38.298 \\
\hline Sp. 9 & 2.11 & 25.124 \\
\hline Sp. 10 & 1.08 & 22.322 \\
\hline Sp. 11 & 0.96 & 18.564 \\
\hline Sp. 12 & 0.48 & 17.467 \\
\hline Sp. 13 & 0.43 & 14.786 \\
\hline
\end{tabular}

Naphthalene has often been used as a model compound to investigate the ability of bacteria to degrade PAHs because it is the simplest and the most soluble PAH. Among thirteen isolates that we have obtained, based on the production and the activity of biosurfactant we selected four of them to examine further their ability to degrade naphthalene. the result showed that all isolated were able to degrade naphthalene. Both isolates Sp. 4 and Sp. 7 were able to reduce the naphthalene concentration up to 99\%. Meanwhile isolate Sp. 13 showed the lowest ability to degrade naphthalene with reduction of $45.7 \%$ (Table 5). This result confirmed what Berthrand (1994) achieved. It was said that microorganism with high production of biodurfactant shows high ability of hydrocarbon degradation. Isolate Sp. 13 showed the smallest concentration of biosurfactant and the lowest biosurfactant activity. One possible explanation for the higher degradation rates is that naphthalene could act as carbon and energy sources. (Johnsen et al., 2005).

Many bacteria that have been isolated and utilize naphthalene as a sole source of carbon and energy belong to the genera Alcaligenes, Burkholderia, Mycobacterium, Polaromonas, Pseudomonas, Ralstonia, Rhodococcus, Sphingomonas, and Streptomyces ( Kang et al., 2003; Hedlund et al., 2001; Pumphrey \& Madsen, 2007) 
Table 5. Naphthalene residue after 15 days of incubation. The initial naphthalene concentration was 20.000 ppm.

\begin{tabular}{lll}
\hline $\begin{array}{l}\text { Bacterial } \\
\text { Isolates }\end{array}$ & $\begin{array}{l}\text { The remaining } \\
\text { naphthalene }(\mathrm{ppm})\end{array}$ & $\begin{array}{l}\text { Reduction } \\
\text { proportion }(\%)\end{array}$ \\
\hline $\mathrm{Sp} \mathrm{04}$ & 36.87 & 99.816 \\
\hline $\mathrm{Sp} \mathrm{07}$ & 26.55 & 99.867 \\
\hline $\mathrm{Sp} 10$ & $2,475.61$ & 87.622 \\
\hline $\mathrm{Sp} \mathrm{13}$ & $10,863.20$ & 45.684 \\
\hline
\end{tabular}

Note: the initial naphthalene concentration was 20.000 ppm.

\section{REFERENCES}

Abraham, T.J., S.A. Shanmugam, A. Uma, R. Palaniappan, and K. Dhevendaran. 2004. Biocontrol of shrimp bacterial pathogenic using Penaeid larva associated bacterium Alteromonas sp. J. Aqua. Trop. 16(1):11-12

Bertrand, J.C., P. Bonin, M. Goutx, M. Gauthier, and G. Mile. 1994. The Potential application of biosurfactant in combating hydrocarbon polution in marene environment. Res. Microbiol. 145: $53-56$

Chandrasekaran, E.V. and J.N. BeMiller. Constituent analysis of glucose aminoglycans p. 89-96 In: R.L.Whistler (ed). Methods in Carbohydrate Chemistry, Academic Press, Inc. New York.

Fachrudin. 2004. Dampak tumpahan minyak pada biota laut. http://cdc.eng.ui.ac.id/article/ articleview/1078/1/25 (accessed on: 20 May 2005)

Gautam, K.K. and V.K. Tyagi. 2006. Microbial surfactants: A Review. J. Oleo Sci. 55 (4):155166

Hedlund, B.P., A.D. Geiselbrecht, J.T. Staley. 2001. Marinobacter strain NCE312 has a Pseudomonas-like naphthalene dioxygenase. FEMS Microbiol. Lett. 201, 47-51.417.

Jain, D.K., D.L.C. Thompson, H. Lee, and J.T. Trevors. 1991. A Drop collapsing Testfor screening surfactant producing microorganism. J. Microbiol. Methods. 13:271-279

Johnsen, A.R., L.Y. Wick, H. Harms. 2005. Principles of microbial PAH degradation in soil. Environmental Pollution 133: 71-84.

Kang, H., S.Y. Hwang, Y.M. Kim, E. Kim, Y.S. Kim, S.K. Kim. 2003. Degradation of phenanthrene and naphthalene by a Burkholderia species strain. Can. J. Microbiol. 49: $39-144$.

Lay, B.W. 1994. Analisis Mikroba di Laboratorium. Penerbit PT. Radja Grafindo Perkasa, Jakarta.

Parra, J.L., J. Guinea, M.A. Manresa, M. Robert, M.E. Mercade, F. Comelles, and M.P. Bosch. 1989. Chemical characterization and Physicochemical behavior of biosurfactant. J. Am. Oil Chem. Soc. 66:141-145

Pumphrey, G.M., and E.L. Madsen. 2007. Naphthalene metabolism and growth inhibition by naphthalene in Polaromonas naphthalenivorans strain CJ2. Microbiology 153: 37303738. 